\title{
ENDOPARASITES OF ROE DEER IN THE STRAKONICE REGION
}

\author{
V. VETY̌SKA
}

\begin{abstract}
Department of Microbiology and Epizootiology and Department of Pathological Morphology 'and Parasitology, University of Veterinary Science, 61242 Brno,

OVZ 38601 Strakonice
\end{abstract}

Received fanuary 24, 1979

\begin{abstract}
Vetýška V.: Endoparasites of Roe Deer in the Strakonice Region. Acta vet. Brno, 48, 1980: $91-103$.

Knowledge on endoparasites of roe deer in Czechoslovakia is relatively comprehensive. However, in the individual regions of roe deer breeding, which differ in abiotic and biotic factors and in the standard of game management, veterinary prophylaxis has not at its disposal any analyses based on conclusive material.

From the Strakonice region, well known for the good condition of roe deer and increasing tendency in quality and amount of hunting trophies, as well as from the transition area to the Sumava Mts, slopes and the Central Bohemian Massive, 112 eviscerations of does, fawns and bucks were examined parasitologically in 1975 and 1976.

Of the endoparasites found were 4 coccidia species, one lungworm species, one tapeworm species, and 13 species of gastrointestinal helminths. Two and 13 species belonged to biohelminths and geohelminths, resp.

The total low frequency of helminthiases, both from the viewpoint of species variety and their extensity and intensity, is due to the timely cultivation of the landscape, favourable climatic factors, low percentage of marshy meadows and pastures, large areas of sweet forage with large-scale management, and good standard of game management, especially for wintering.

The most important task for veterinary diagnostics is to reduce the incidence of lungworms of the species Capreocaulus capreoli; gastrointestinal helminths of the species Ostertagia ostertagi, O. leptospicularis, Trichostrongylus capricola, Tr. axei, Chabertia ovina, Trichocephalus globulosa, and of coccidia of the species Eimeria superba.
\end{abstract}

Capreolus capreolus, helminths, coccidia, prophylaxis.

Roe deer numbers increased after field populations originated - with the exception of extremely high altitudes of more than $1000 \mathrm{~m}$ - over the whole territory of Czechoslovakia. As to the production of game, roe deer belongs to the profile species. They readily adapt even to intensively cultivated landscape. In socialist game management special attention is devoted to the improvement of antlers and also to a planned development; the total amount of hunted animals per year is 100,000 (Nečas 1975; Hromas et al. 1974; Papánek 1974; Zásměta 1968, 1976).

In Czechoslovakia, the health condition of the roe deer has been followed since the beginning of the century. Over the past decades we have succeeded in filling in large gaps, especially in the knowledge on parasites of roe deer.

One of the most important contributions to this problem was Sallač's $(1911,1912)$ summary on lungworms, based on investigations from Bonn, followed by many casuistries which dealt with the most-feared parasitosis of the lungs.

Vostál (1953) performed a more recent revision of lung and intestinal helminths. Erhardová and Kotrlý (1955) eruditely elaborated paratises of ruminants living in the wild. Dyk (1958) dealt with the ecology of cysticercoses of roe deer. Páv and Mottl(1958) investigated the influence of pa- 
rasites on body weight. Kotrlý and Krul (1959) analyzed the pathogenicity of lungworms. Vývl ečka (1960) enumerated the causes of roe deer mortality. Záhoř (1965) reported the occurrence of the large trematode in roe deer. Tománek (1967) summarized his findings from the North Moravian Region. Páv and Zajiček (1969) investigated the dynamics of helminthoses of hoofed game. Dyk and Chroust (1974) compared the parasites in ecologically differing Brno regions following investigations of the exchange of helminths between mouflons and roe deer (1975). Koždoň (1976) studied the endoparasites of hoofed game in the Doupovské Hills. The veterinary aspect of this problem was studied by Kolár (1977). Hovorka et al. (1962) summarized the problems of parasites in roe deer in Slovakia.

Of authors from the countries neighbouring with Czechoslovakia we must mention Wetzel (1937) who provided information from the German hunting districts, Sitowski (1939) who dealt with mülleriosis of roe deer in the Pieniny region, Šulc and Kadenazii (1954) who presented characteristics of trichostrongylids, Boch (1955) who described the helminthofauna of roe deer in the mountains of Bavaria, Drozdz $(1959,1966)$ in Poland and Stoican-Olteanu (1959) in Rumania. Boye and Rieck (1961) studied the influence of helminthoses on antler development in the German Democratic Republic, Wecker (1966) studied the effect of helminthoses on the population dynamics of roe deer, Kirschlagl (1967) dealt with lung infestation of roe deer and grazing cattle in Austria, Kutzer and Knaus (1968) studied the ecology of roe deer parasitoses, Gräfner, Eichhorn and Benda (1969) investigated the effect of roe deer on the infestation of pastures, and so did Kutzer and Hinady (1969).

\section{Materials and Methods}

Origin of the material and characteristics of the environment

In 1975, 112 eviscerations were obtained (from 29 does, 75 fawns and 8 bucks) during routine autumn regulation executed in 17 Hunting Associations of the Strakonice region from animals, namely does and fawns, unsuitable for further breeding.

The age of the killed animals was estimated according to the wear of the molars. The fawns were 6-7 months old, as to the variability of the actual date of birth.

For our studies mostly does and fawns were used because their eviscerations could be transported in a utilizable condition to the laboratory only during the cooler autumn weather. Another important reason is the fact that the invasion cycles are under full development in the last months of the year, they have already affected the young as well and are, therefore, significant for assessing the parasitological state of the region.

The altitudes of the localities studied range within $392-550 \mathrm{~m}$. They are situated in a slightly hilly terrain (Figs. 1-6) and also on the slopes of the Sumava Mts., and they reach the promontory of the Vodñany Basin and, to the north, the Central Bohemian Massive.

The parent rock consists of gneiss with abundant veins of crystallic limestone in the Volyně district. The soil type is brown soil with clayey, sandy-clayey and stony soil types (Slavik et al. 1929).

The original beech forests were gradually transformed into the predominantly coniferous stands of today.

Climatologically the region belongs to the moderately warm regions, during the vegetation period the temperatures average $13^{\circ} \mathrm{C}$. There are 40 summer days, 120 frosty days (in the Volyně and Blatná districts 130 days) (Syrový et al. 1958).

The average total precipitations are $500 \mathrm{~mm}$ (in the Volyně and Blatná districts $600 \mathrm{~mm}$ ). During the vegetation period the amount of rainfall is $400 \mathrm{~mm}$ and winter precipitations are $200 \mathrm{~mm}$ only. There are only 20 days with snowfall, the maximum snow cover is $20 \mathrm{~cm}$ and lasts 120 days.

In the Strakonice region there are 40 sunny days, 140 cloudy days, and $40-50$ foggy days. The sun shines 1700 hours ( 1300 hours during the vegetation period). There are 25 days with thunderstorms.

In general, the climatic factors are very favourable for roe deer, their food basis, as well as for the development of the fawns and their first wintering season; all these factors are reflected in the performance of this game and in the formation of antler trophies which are of good, even excellent, quality.

The land of the district consists of $70 \%$ of fields, $20 \%$ of forests, $3 \%$ of ponds $(50 \%$ is arable land, $13 \%$ meadows, and $4 \%$ pastures).

A total number of 2.324 roe deer is hunted every year, the total weight being $29.040 \mathrm{~kg}$. The game stocks of some of the hunting associations are excessive and in some places there is a decreasing tendency in weight per animal of the individual sex and age categories of the hunted roe deer due to excessive game stocks. 
Cereal growing on large areas with increasing areas of maize and clover-lucerne stands and also grasse on arable land, the improvement of meadows and a neglectible area of pastures, along with an increasing standard of game management, very significantly shifted the effectivity of roe deer breeding.

\section{Parasitological investigations}

The forestomachs, lungs and parts of liver for orientation purposes were investigated immediately at the place of shooting. Eviscerations containing lungs, liver, spleen, the large and small intestines were transported for dissection.

Laboratory investigations proper were performed using the method of complete helminthological dissection according to Academician Skryabin.

When dissecting the lungs, first attention was paid to the presence of any parasitary nodes. Next, microscopical examination of bronchial mucus was performed. From a part of the hatching nodes compression preparations were made and examined microscopically.

The intensity of invasions was evaluated as follows: + sporadic nodes, ++ numerous nodes, +++ mass occurrence of nodes on the surface as well as in the lung parenchyma.

Dissective examinations of the lungs were completed with larvoscopical examinations of faeces samples taken from the caudal part of the intestine (Baermann's method).

Complete helminthological dissection was used also for examinations of liver.

From faeces samples taken from the caudal part of the intestine, coccidia were found using the flotation method according to Breza.

Determination of isolated helminths was performed after clarification with lactophenol or glycerin jelly according to the monographs of Skryabin (1952, 1954, 1955), Kotlán (1960), Erhardová and Kotrlý (1955), and Dyk et al. (1969).

Coccidia were determined according to Pellérdy (1965) and Chroust (1975).

\section{Results}

The following endoparasite species of roe deer were determined in the Strakonice region studied:

Coccidia - Eimeria superba Pellérdy, 1955

Eimeria ponderosa Wetzel, 1942

Eimeria panda Supperer-Kutzer, 1961

Eimeria capreoli Galli-Valerio, 1927

Lungworms - Capreocaulus capreoli Stroh-Schmid, 1938

Tapeworms - Moniezia benedeni Moniez, 1879

Intestine - Haemonchus contortus Rudolphi, 1803

nematodes Ostertagia leptospicularis Assadov, 1953

Ostertagia ostertagi (Stiles, 1892) Ransom, 1902

Ostertagia lasensis Assadov, 1953

Spiculopteragia böhmi (Gebauer, 1932) Orlov, 1933

Trichostrongylus capricola Ransom, 1902

Trichostrongylus axei (Cobbold, 1897) Railliet-Henry, 1909

Trichostrongylus minor Mönning, 1932

Nematodirus filicollis Rudolphi, 1802

Chabertia ovina Gmelin, 1790

Oesophagostomum venulosum Rudolphi, 1809

Trichocephalus capreoli Artuch, 1948

Trichocephalus globulosa Linstow, 1901

None of the eviscerations was absolutely free from endoparasites.

Only one of the species determined was found to occur in the Strakonice sub-regions, i. e. in 3-5 eviscerations ( 9 fawns, 3 two-year old animals).

In 63 fawns and 35 older animals, two or more endoparasite species were found.

The maximum species invasion in one host was 15 species in a six-month old young doe. 
Table 1

Comparison of species and extensity of endoparasite occurrence in the region studied (in \%)

\begin{tabular}{|c|c|c|c|c|}
\hline Species & $\begin{array}{c}\text { Opava region } \\
\text { (Tománek, } \\
\text { 1967) }\end{array}$ & $\begin{array}{c}\text { Brno region } \\
\text { (Dyk - Chroust, } \\
\text { 1974) }\end{array}$ & $\begin{array}{c}\text { Doupovské } \\
\text { Hory, } \\
\text { (Koždon̆, 1976) }\end{array}$ & $\begin{array}{c}\text { Strakonice } \\
\text { region } \\
\text { (author's own } \\
\text { findings in 1975) }\end{array}$ \\
\hline Fasciola hepatica & 11.7 & - & - & - \\
\hline Moniezia benedeni & 1.9 & 7.4 & - & 0.9 \\
\hline Cysticercus tenuicollis & 7.8 & - & - & - \\
\hline Capreocaulus capreoli & $\mathbf{7 8 . 4}$ & 77.0 & 25.5 & 31.0 \\
\hline Dictyocaulus viviparus & 56.8 & $\mathbf{2 2 . 0}$ & 40.4 & - \\
\hline Haemonchus contortus & 49.0 & 55.0 & 100.0 & 10.7 \\
\hline Ostertagia leptospicularis & 43.1 & 88.0 & 4.2 & 83.9 \\
\hline Ostertagia ostertagi & 27.4 & 37.0 & 57.4 & 52.7 \\
\hline Ostertagia lasensis & - & 74.0 & - & 12.5 \\
\hline Ostertagia trifurcata & - & 38.0 & 27.6 & - \\
\hline Ostertagia circumcincta & 3.9 & - & 48.9 & - \\
\hline Spiculopteragia böhmi & 41.1 & 55.0 & - & 19.6 \\
\hline Spiculopteragia spiculoptera & - & - & 57.4 & 1 \\
\hline Trichostrongylus capricola & 15.7 & 26.0 & - & 41.0 \\
\hline Trichostrongylus axei & 43.1 & 30.0 & 21.1 & 16.0 \\
\hline Trichostrongylus colubriformis & 3.9 & - & 29.7 & - \\
\hline Trichostrongylus minor & - & 11.0 & - & 7.1 \\
\hline Nematodirus filicollis & 29.4 & 22.0 & 19.1 & 3.6 \\
\hline Nematodirus spathiger & - & - & 8.5 & - \\
\hline Chabertia ovina & 31.3 & $\mathbf{7 7 . 0}$ & 31.9 & 42.9 \\
\hline Oesophagostomum radiatum & - & - & 12.7 & - \\
\hline Oesophagostomum venulosum & 5.9 & 22.0 & - & 0.9 \\
\hline Trichocephalus capreoli & 11.7 & 52.0 & - & 8.9 \\
\hline Trichocephalus globulosa & 1.9 & - & 34.0 & 21.4 \\
\hline Trichocephalus ovis & 11.7 & - & 61.7 & - \\
\hline Skrjabinagia kolchida & - & - & 40.4 & - \\
\hline Rinadia mathevosiani & - & - & 8.5 & - \\
\hline Bunostomum trigonocephalum & 7.8 & - & 2.1 & - \\
\hline Cooperia pectinata & - & 18.0 & - & - \\
\hline Muflonagia podjapolskyi & 62.7 & - & - & - \\
\hline Strongyloides papillosus & 7.8 & - & - & - \\
\hline Eimeria superba & & 50.0 & & 40.0 \\
\hline Eimeria capreoli & & 30.0 & & 10.0 \\
\hline Eimeria ponderosa & & 60.0 & & 13.0 \\
\hline Eimeria panda & & 30.0 & & 15.0 \\
\hline
\end{tabular}

No case of fasciolosis was observed, despite the fact that it occurs in heavy invasions in cattle of the Strakonice region.

Remarkable is the early onset of invasions in fawns and in the oldest hunted animals, at about 5 months and 7 years, respectively.

In the older animals there is a distinct decrease in the occurrence of coccidioses, contrasting with the increasing occurrence of helminthoses, the re-invasions of which contribute to the preservation and distribution of parasiting worms.

Very rare is biohelminthic Moniezia, so that the main pathogens of the studied region of Strakonice are lungworms and gastroenterohelminths.

The situation in the occurrence and effect of coccidia is given in the comparative table of frequencies of parasitoses in roe deer with those regions of Czechoslovakia studied earlier on more conclusive material (Tabs. 1-2).

If we compare 4 naturally completely different regions with a different economic utilization, different representation and numbers of hoofed game (the latter being the highest in the Opava and Strakonice regions), we get the following order: according to Tománek there are 22 species of roe deer helminths in the Opava region, according to Koždoň there are 19 species in the Doupovské Hills (where roe deer graze on a relatively large area), according to Dyk and Chroust there are 17 species in the Brno region (Krrtiny), in the Strakonice region only 15 species. 
The extensity of invasions of 9 species in the Brno region, 3 species in the Opava region, 3 species in the Doupovské Hills, and of only one species (Ostertagia leptospicularis) in the Strakonice region is higher than $50 \%$.

In the regions studied in greater detail, the extensity differed considerably (Tab. 1), on the one hand in the occurrence of Fasciola hepatica, of which the roe deer of the Opava region are co-preservers, whereas in the other three regions there were no findings; on the other hand, in the occurrence of the highly pathogenic lungworm Capreocaulus capreoli, the intensity of which is very high in the Opava and Brno regions (i. e. 78 and $77 \%$, resp.), but two times lower in the Strakonice region (31\%). In the Doupovské Hills it is $25.5 \%$.

Haemonchus contortus occurs in the Strakonice region in $10 \%$ only.

The invasions of Ostertagia in the Strakonice region are very heavy, or moderately heavy, with the exception of Ostertagia lasensis (only $12.5 \%$ ), and Ostertagia trifurcata and Ostertagia circumcincta which in the Strakonice region were not found at all.

Spiculopteragia böhmi which infests about one half of the populations of the Opava and Brno regions, occurred in the Strakonice region in $20 \%$ only.

The extensity of Trichostrongylus capricola was highest in the Strakonice region

Table 2

Comparison of the intensity of endoparasites occurrence (minimum and maximum invasion) in the regions studied

\begin{tabular}{|c|c|c|c|c|c|c|}
\hline \multirow[t]{2}{*}{ Species } & \multicolumn{2}{|c|}{$\begin{array}{c}\text { Brno region } \\
\text { (Dyk - Chroust, 1974) }\end{array}$} & \multicolumn{2}{|c|}{$\begin{array}{l}\text { Doupovské Hory } \\
\text { (Koždoñ, 1976) }\end{array}$} & \multicolumn{2}{|c|}{$\begin{array}{c}\text { Strakonice region } \\
\text { (author's own findings, } \\
\text { 1975) }\end{array}$} \\
\hline & $\min$. & $\max$ & $\min$. & $\max$. & $\min$. & $\max$. \\
\hline Moniezia benedeni & 1 & 1 & - & - & 1 & 1 \\
\hline Capreolus capreoli & + & +++ & 1 & 27 & + & ++ \\
\hline Dictyocaulus viviparus & 2 & 35 & 2 & 60 & - & - \\
\hline Haemonchus contortus & 2 & 42 & 30 & 3000 & 1 & 29 \\
\hline Ostertagia leptospicularis & 9 & 684 & 5 & 13 & 1 & 133 \\
\hline Ostertagia ostertagi & 4 & 43 & 8 & 321 & 1 & 92 \\
\hline Ostertagia lasensis & 15 & 596 & - & - & 2 & 7 \\
\hline Ostertagia trifurcata & 2 & 32 & 1 & 17 & - & - \\
\hline Ostertagia circumcincta & - & - & 8 & 2380 & - & - \\
\hline Spiculopteragia böhmi & 12 & 104 & - & - & 1 & 7 \\
\hline Spiculopteragia spiculoptera & - & - & 3 & 251 & - & - \\
\hline Trichostrongylus capricola & 1 & 22 & - & - & 1 & 93 \\
\hline Trichostrongylus axei & 4 & 28 & 4 & 21 & 1 & 30 \\
\hline Trichostrongylus colubriformis & - & - & 2 & 19 & - & - \\
\hline Trichostrongylus minor & 3 & 14 & - & - & 1 & 8 \\
\hline Rinadia mathevossiani & - & - & 1 & 19 & - & - \\
\hline Nematodirus filicollis & 6 & 18 & 30 & 300 & 1 & 4 \\
\hline Nematodirus spathiger & - & - & 29 & 198 & - & - \\
\hline Chabertia ovina & 1 & 145 & 40 & 400 & 1 & 102 \\
\hline Oesophagostomum venulosum & 1 & 15 & - & - & 1 & 1 \\
\hline Oesophagostomum radiatum & - & - & 2 & 16 & - & - \\
\hline Trichocephalus capreoli & - & 15 & - & - & 1 & 27 \\
\hline Trichocephalus ovis & - & - & 2 & 29 & - & - \\
\hline Trichocephalus globulosa & - & - & 7 & 59 & 1 & 143 \\
\hline Skrjabinagia kolchida & - & - & 1 & 85 & - & - \\
\hline Cooperia pectinata & 4 & 18 & - & - & - & - \\
\hline Bunostomum trigonocephalum & - & - & 1 & 2 & - & - \\
\hline Eimeria superba & + & +++ & & & + & ++ \\
\hline Eimeria capreoli & + & ++ & & & + & + \\
\hline Eimeria ponderosa & + & +++ & & & + & + \\
\hline Eimeria panda & + & ++ & & & + & + \\
\hline
\end{tabular}

Note: For lungworms + indicates less than 30 larvae in $5 \mathrm{~g}$ of faeces, $++30-100$ larvae, +++ more than 100 larvae in $5 \mathrm{~g}$ of faeces

For coccidia + characterizes a sporadic occurrence of oocysts in the viewing field, +++ indicates a mass invasion, ++ indicates the situation between these two extremes (moderately heavy invasion) 
- $41 \%$, whereas the occurrence of Trichostrongylus axei is the reverse $-43 \%$ in the Opava region and only $16 \%$ in the Strakonice region.

The incidence of Nematodirus filicollis in the Strakonice region is minimum, i. e. only $3.6 \%$.

The extensity of Chabertia ovina is $77 \%$ in the Brno region and $43 \%$ in the Strakonice region.

Oesophagostomum venulosum is very rare in the Strakonice region, only $0.9 \%$. The occurrence of Trichocephalus capreoli in the Brno region is $52 \%$, in the Strakonice region only $8.9 \%$. Trichocephalus globulosa abundant in the Doupovské Hills $(34 \%)$, occurs only in $21 \%$ in the Strakonice region.

Other helminths given by the quoted authors cannot be compared because, as a rule, they occur only in one or two regions.

The extensity of the 4 coccidia species found, investigated only in the Brno and Strakonice regions, is $30-60 \%$ in the Brno region, while in the Strakonice region the values range according to the species from 14 to $40 \%$.

Of the 4 regions compared, from which conclusive material was elaborated, the least invested was found to be the Strakonice region in terms of species variety and extensity of helminths found. In comparison with the Brno region the extensity of coccidioses was also many times lower.

As far as the intensity of endoparasitoses (Tab. 2) is concerned, only 3 regions can be compared because Tománek (1967) provides no data from the Opava region. The differences are even more marked than in the extensity.

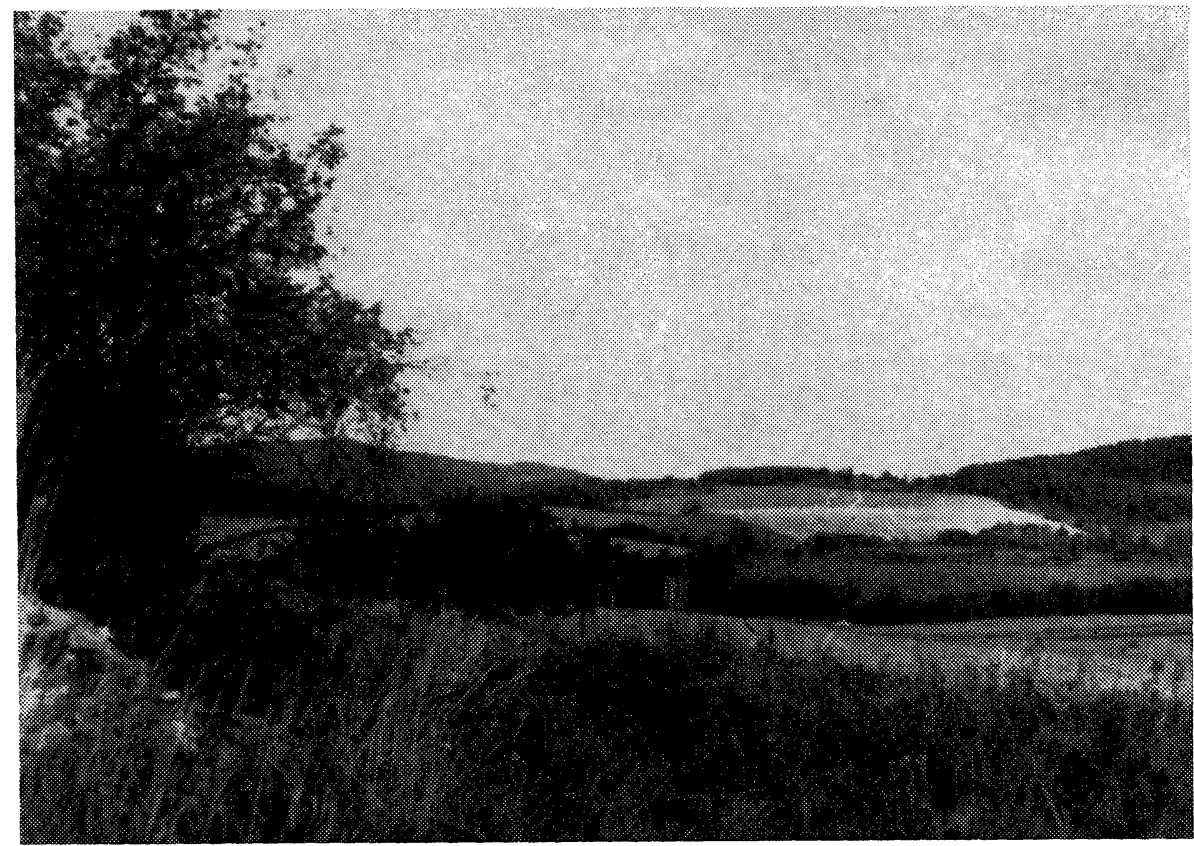

Fig. 1.

In the moderately hilly Strakonice region studied, also samples of the original biotopes and their biocenoses are preserved 


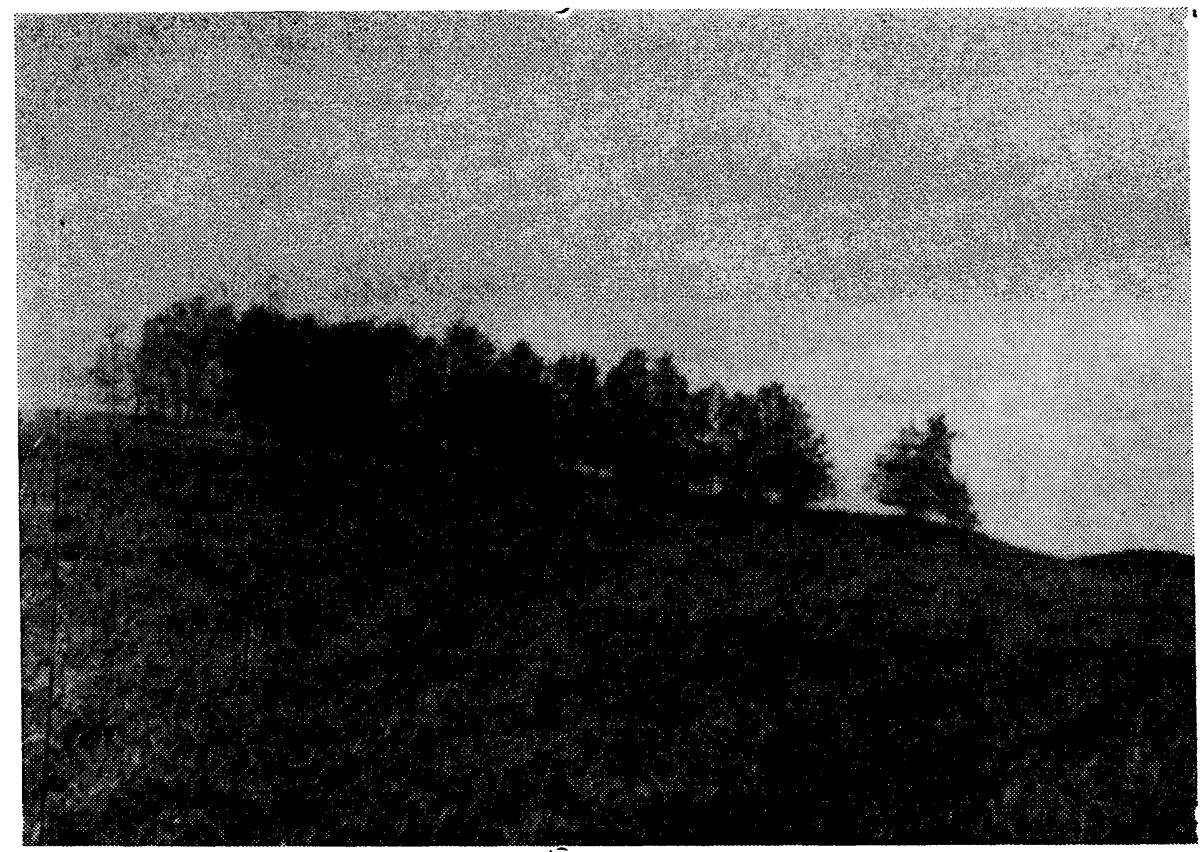

Fig. 2.

Smaller copses in the consolidated land serve the physiological needs of roe deer (quickly drying terrain, dietetic herb cover, woody species for browsing, etc.)

The invasion of lungworms of the species Capreocaulus capreoli in the Doupovské Hills and Strakonice region are mild or moderately heavy, while in the Brno region they can even be massive.

Haemonchus contortus, of which as many as 3000 worms were found in one roe deer in the Doupovské Hills, did not exceed 29 worms in the Strakonice region.

The maximum intensity of Ostertagia leptospicularis in the Brno and Strakonice regions was 684 and 133, resp.

The maximum intensity of Ostertagia ostertagi in the Doupovské Hills and Strakonice region was 321 and 92 , resp.

The maximum intensity of Ostertagia lasensis in the Brno region is 596, in the Strakonice region its incidence is very rare (7).

The incidence of Spiculopteragia böhmi (maximum of 104 in the Brno region) is similar to $O$. lasensis.

The incidence of 93 Trichostrogylus capricola worms in the Strakonice region exceeded the maximum intensity in the Brno region (22) four times.

The intensity of Trichostrongylus axei in the three regions compared is very close $(21-30)$.

The maximum intensity of Trichostrongylus minor in the Brno and Strakonice regions was 14 and 8, resp.

Nematodirus filicollis, whose maximum intensity in the Doupovské Hills is 400, was only sporadic in the Strakonice region (4).

The maximum intensity of Chabertia ovina in the Doupovské Hills, Brno and Strakonice regions is 400,145 and 102, resp. 
Table 3

Profile helminths in the Strakonice region according to the maximum intensity (incl. extensity) of occurrence and age of host

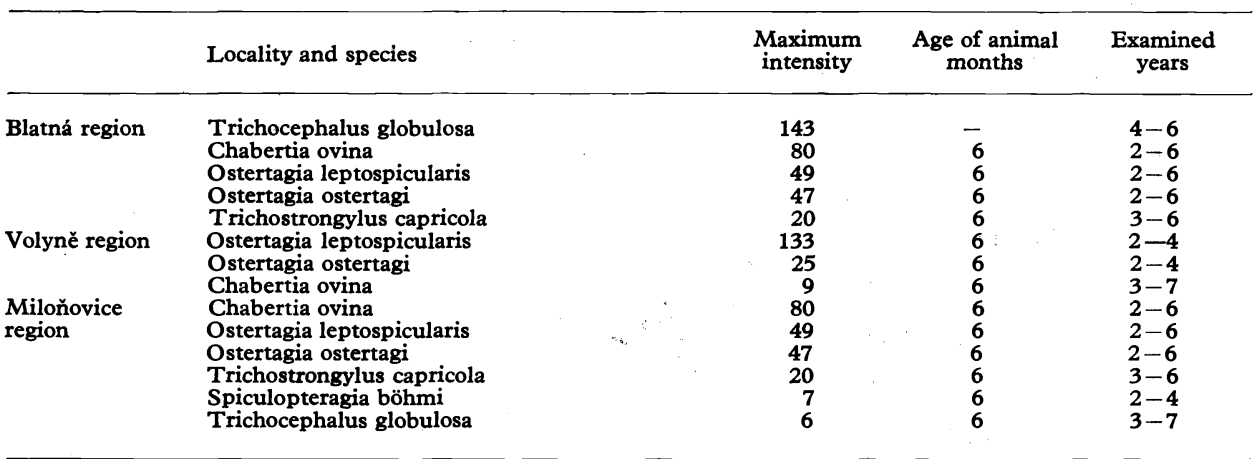

The incidence of Oesophagostomum venulosum in the Brno region was 15, however, in the Strakonice region only one specimen was found.

The intensity of Trichocephalus capreoli in the Brno and Strakonice regions was 15 and 27, resp.

The intensity of Trichocephalus globulosa in the Doupovské Hills was 59, in the Strakonice region it was remarkably high, i. e. 143.

The intensity of coccidia in the Brno region is two to three times higher than elsewhere. Eimeria superba attacks roe deer in mass invasions in the Brno region, while in the Strakonice region the invasions are only moderately heavy. The other three species found were found to occur only sporadically in the Strakonice region.

Tab. 3 shows the relationship of pathogenic profile species of helminths (found from the survey of the extensity and intensity for the Strakonice region) to the age of the host.

It shows the early infestation of the fawns already during the first months of life; next, it shows that lungworms prevail only in animals older than 2 years, finally, that re-invasions with gastroenterohelminths occur in animals of 6-7 years of age. The onset can, in most cases, be observed at 6 months of age, but can be observed at the age of $2-3$ years as well. In the fawns there was a distinct prevalence of one species of coccidia, in contradistinction to older animals. In the closer vicinity of Strakonice, for example, only one two-year old doe was infested as compared to 20 infested fawns.

Moniezia benedeni belongs to the extremely rare helminths of roe deer of the Strakonice region; in the non-significantly low percentage of marshy meadows amount of interhost soil mites is not sufficient enough.

\section{Discussion}

It is surprising that the species variety of endoparasites of roe deer in the Strakonice region is very low, i. e. 4 coccidia species, one lungworm species, one tapeworm species, and 13 species of gastrointestinal helminths, and that also their extensity and intesity is low. This finding is all the more surprising with regard to data provided by Kotrlý (1964) who gave 37 species of parasiting worms for the whole territory of Czechoslovakia, and with regard to the rapid increase of 


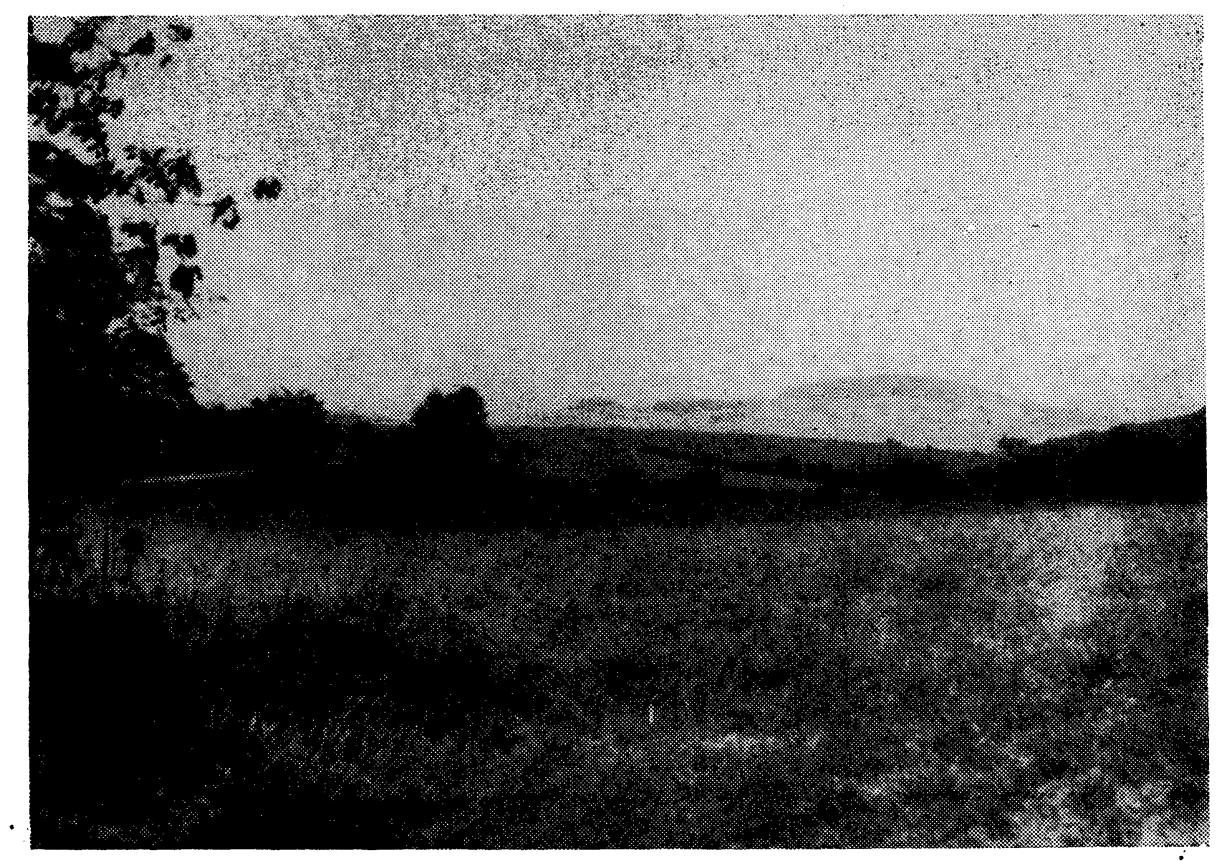

Fig. 3.

In the shallow cuts of the Milonovice and Strunkovice regions the game find lee and sunlit areas speeding strong antler growth

game stocks after World War II, in some hunting associations even overstocking which in some places leads to the decrease in weight per animal.

The strikingly lower incidence of parasites, especially of geohelminths, mostly extremely pathogenic, as well as of coccidia, enable the improvement in trophies development which is a very important component of the attractivity of roe deer and their rearing.

We can obtain an objective explanation only by analyzing the economic development and intesity of exploitation of the Strakonice region and its present ecological spectrum, along with the standard of game care.

The conditions favourable for the existence of endoparasites were worsened due to timely meliorations, drainage of marshy meadows and reduction of their area, abandoning the grazing of cattle, and, finally, also the transition to large-scale cereal production which improves the soil physically and chemically and together with full-dose fertilization destroys parasite germs.

A very important factor for roe deer resistance and decrease of parasite incidence has been the considerably improved feed basis. Large areas of lucerne and sweet forage stands, forage on arable land, and maize stands enable a rapid body development, recuperation after the winter season and rutting. Besides, in stands of maize grown for grain the game finds its necessary cover and repose. The sloping terrains with balks provide important dietary components. The standard of supplementary winter feeding has an increasing tendency, bringing along an improve- 


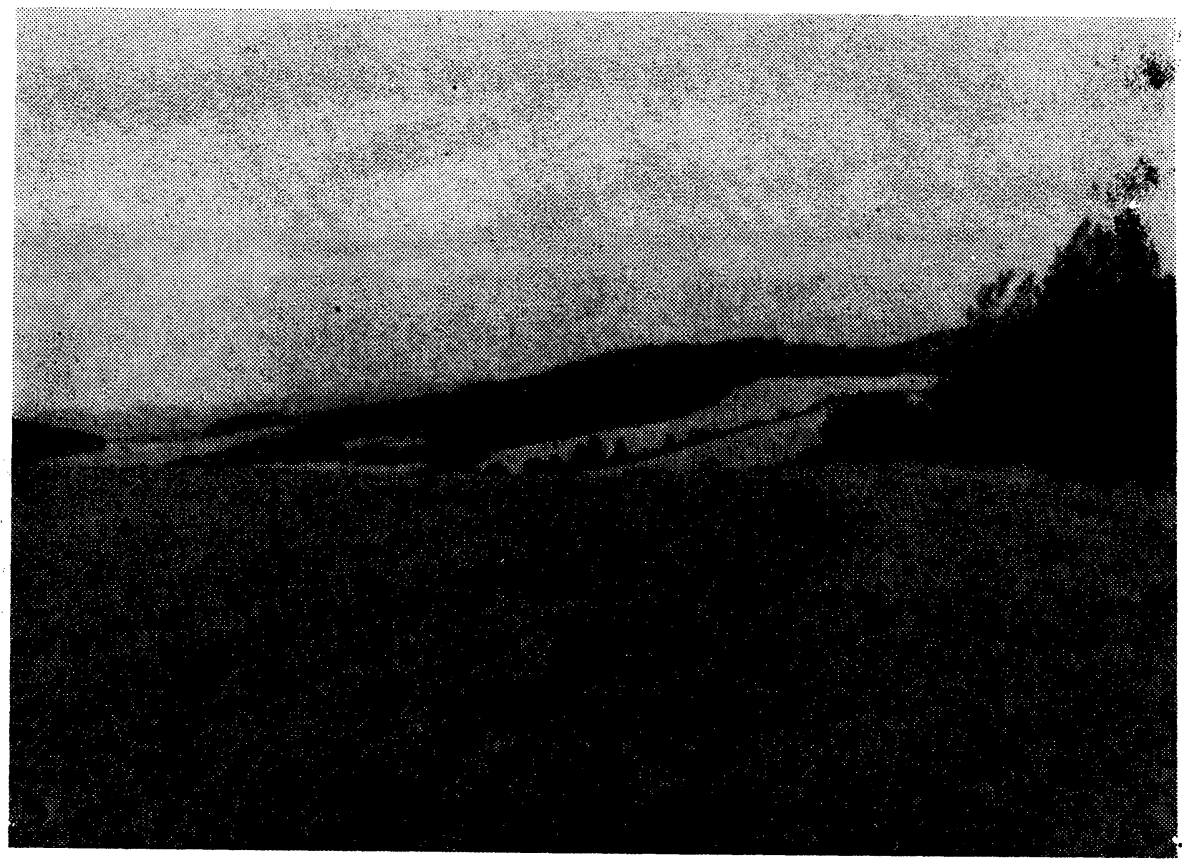

Fig. 4.

Large areas of sweet forage on arable land, cereals, and forest environment enabled the quick growth of original forest populations and the more recent field populations of roe deer

ment in the ratio between sexes, representation of the individual age categories and negative selection of animals unsuitable for further breeding.

The climatic factors of the warmer island of the Strakonice region and the mild temperature of the landscape towards the Central Bohemian Massive and its slopes, favourable distribution of precipitation, amount of sunshine during the year, besides others, enable the development of strong young animals well capable of overwintering.

The Strakonice region studied shows in a model way that an effective cultivation of the landscape in the course of the past decades can considerably reduce parasitoses, namely coccidioses and helminthoses, and can evoke resistance of the populations and an increasing trend in some factors of performance.

It was also the origin of field populations of roe deer in the Strakonice region which influenced the epizootiological and parasitological situation. A part of the game stock permanently left the forest stands which had, for centuries, been invaded with parasites, where roe deer found cover and food, where the fawns were born and where also secondary foci of diseases originated, and came to live in a relatively healthier and ever improving environment.

However, even such an environment becomes dangerous in the case of excessive game stocks, as the intensity of endoparasite transmission is much higher in dense populations. This danger can be averted by erecting more feeding places, effectively distributed and well supplied, and salt licks. 
The main task of veterinary diagnostics and regional game specialists in the Strakonice region is to control the dynamics of lungworms of the species Capreocaulus capreoli, gastrointestinal helmints of the species Ostertagia ostertagi, Ostertagia leptospicularis, Trichostrongylus capricola, Trichostrongylus axei, Chabertia ovina, Trichocephalus globulosa, and of coccidia namely the species Eimeria superba.

During the winter season curative and preventive measures can be applied in close cooperation with gamekeepers and members of hunting associations.

Prior to all these activities for the improvement of roe deer, which is so important for national economy as well for recreation and sporting, it is necessary to know the species representation and dynamics of the parasitofauna obtained from conclusive numbers of eviscerations and faeces samples. It is also necessary to be well informed about and to objectively evaluate the whole ecological spectrum of the landscape which is managed by the individual hunting associations and State Forests.

\section{Endoparaziti srnčí zvěře na Strakonicku}

Endoparaziti srnčí zvěře jsou již v ČSSR známí dosti uceleně. V jednotlivých oblastech chovu, lišících se abiotickými a biotickými faktory, i úrovní mysliveckého hospodaření, nemá však veterinární prevence $\mathrm{k}$ dispozici analýzy získané $\mathrm{z}$ průkazných materiálů.

Ze Strakonicka, známého velmi dobrými stavy této zvěře a vzestupnou tendencí $\mathrm{v}$ její trofejovosti a $\mathrm{z}$ jeho přechodu $\mathrm{k}$ šumavskému podhưứi a $\mathrm{k}$ středočeskému masivu bylo v r. 1975 a 1976 prozkoumáno parazitologicky 112 vývrhů srn, srnčat a srnců.

Z endoparazitů byly zjištěny 4 druhy kokcidií, 1 druh plicnivek, 1 druh tasemnic a 13 druhů gastrointestinálních helmintů. $\mathrm{K}$ biohelmintům patřily 2 druhy, do skupiny geohelmintů 13 druhů.

Celkově nízkou frekvenci helmintóz, jak $\mathrm{z}$ hlediska pestrosti druhů, tak jejich extenzity, a intenzity, podmiňuji včasná kultivace krajiny, výhodné klimatické faktory, malé procento bažinatých luk a pastvin, velké plochy sladkých pícnin velkoplošného hospodářství a dobrá úroveň myslivecké péče, zvláště při zimování.

Veterinární diagnostika i speciální práce hygieniků zvěře mají zde nejaktuálnější úkoly v tlumení plicnivek druhu Capreocaulus capreoli, gastrointestinálních helmintů druhů Ostertagia ostertagi, Ost. leptospicularis, Trichostrongylus capricola, Tr. axei, Chabertia ovina, Trichocephalus globulosa a z kokcidií druhu Eimeria superba.

\section{Эндопаразиты косулей Страконицкого края}

Эндопаразиты косулей в ЧССР изучены достаточно подробно. Однако, у ветеринарной профилактики по отдельным областям, отличающимся абиотическими и биотическими факторами, а также уровнем охотничьего дел:, не имеются анализы, полученные на основе достоверных материалов.

В Страконицком крае, отличающемся хорошим состоянием данной дичи и возрастающей тенденцией результатов охоты, и на промежуточной территории шумавского предгорья и среднечешского массива в 1975-1976 гі. проводились паразитологические исследования 12 приплодов серн, пыжиков и самцев косули.

Из эндопаразитов были выявлены 4 вида кокцидий, 1 вид Capreocaulus 
capreoli, 1 вид солитеров и 13 видов гастроинтестинальных. гельминтов. Б биогельминтам принадлежали 2 вида и в группу геогельминтов входили 13 видов.

Низкое общее число гельминтозов, не только с точки зрения разнообразия видов, но и әкстенсивности и интенсивности, обусловлено своевременной культивацией местности, выгодными климатическими факторами, небольшим процентом болотистых лугов и пастбищ, большими площадями сладких кормов крупных хозяйств и хорошим уровнем охотничьего дела, в особенности в зимний период.

Актуальнейшаяа задача, стоящая перед ветеринарной диагностикой и специальной деятельностью гигиенистов животных, заключается в приглушении вида Capreocaulus capreoli, гастроинтестинальных гельминтов видов Ostertagia ostertagi, Ost. leptospicularis, Trichostrongylus capricola, Tr. axei, Chabertia ovina, Trichocephalus globulosa и кокцидий вида Eimeria superba.

\section{References}

BOCH, J.: Der Wurmbefall des Reh- und Rotwildes in den bayerischen Bergen. Tierärztl. Umsch. 10, 1955: 249-252.

BOYE, F. - RIECK, W.: Magenwurmbefall und Gehörnbildung. Deutsch. Jäger-Zeit. 19, 1961: 415.

BREZA, M.: Zlepšenie metodiky koproovoskopického vyšetrovania trusu ošípaných s použitím nového flotačného roztoku a mukogélu. Vet. čas. 6, 1959: 569-576.

ČABART, J.: Vývoj české myslivosti. Praha, 1958: 98-99.

DROŹDŹ, J.: Rzadki pasozyt sarny, Capreolus capreolus L. - Ostertagia asymetrica Ware, 1925 po raz pierwszy stwierdzony w Polsce. Wiad. Paraz., 4, 1959: 723-724.

DROŹDŹ, J.: Studies on helmints and helminthiasis in Cervidae. Acta parasitol. pol., 14, 1966: $287-300$.

DYK, V.: Cysticerkóza srnčí zvěře v ekologickém profilu. Sbor. VŠZL Brno, B, 27, 1958: 259 až 264.

DYK, V. - CHROUST, K. - ZAVADIL, R.: Parazitologie a invazní choroby. Brno, 1969, pp. 165.

DYK, V. - CHROUST, K.: Helminths and Coccidia of roe deer in two neighbouring ecologically different regions. Acta vet. Brno, 43, 1974: 65-77.

DYK, V. - CHROUST, K.: Směnnost kokcidií a helmintů mezi muflony a srnčí zvěří. Paraz. aktual., Rašínovy dny, 16. 20. 1974: 4-7.

DYK, V. - CHROUST, K.: The incidence and possible cross transmission of Coccidia and Helminths in the mouflon and roe deer in Czechoslovakia. Veter. parasit., 1, 1975: 145-150.

ERHARDOVÁ, B. - KOTRLÝ, A.: Cizopasní červi zažívacího ústrojí našich volně žijících přežvýkavců. Čs. paraz., 2, 1955: 41-57.

GRÄFNER, G. - EICHHORN, G. - BENDA, A.: Zur Rolle des Rehwildes bei der Verseuchung der Rinderweiden mit Lungenwurmlarven. Mh. Vet. Med., 24, 1969: 412-413.

HOVORKA, J. - BREZA, M. - JURÁSEK, V.: Parazitárne choroby polovnej zveri. In Polovníctvo I, Bratislava, 1962: 459-498.

HROMAS, J. - LOCHMAN, J. - MACOUREK, J.: Lovecké trofeje českých zemí. Praha, 1974, pp. 277.

CHROUST, K.: Kokcidie u domácích a volně žijících přežvýkavců. Pardubice, 1975, pp. 38.

KERSCHAGL, W.: Lungenwurmseuche, Rehwild und Weidevieh. Österr. Wiedwerk, 5, 1967: $208-210$.

KOLÁR̆, Zd.: Základní veterinární problematika u spárkaté zvěře. Myslivost, 1977: 6-7.

KOTLÁN, A.: Helminthologia. Budapest, 1960: 378-481.

KOTRLY̛, A.: Ekologie cizopasniků spárkaté zvěre čeledi Cervidae, Bovidae a Suidae v ČSSR. Práce výzk. úst. lesn., 29, 1964: 7-47.

KOTRLÝ, A. KRUL, J.: Plicní cizopasníci spárkaté zvěře v ČSR a několik poznámek $\mathrm{k}$ jejich patigenitě. Lesnictví CSAZV, 5, 1959: 559-564.

KOŽDOŇ, O.: Srovnávací výzkum helmintofauny spárkaté zvěře a pasených domácích přežvýkavců v oblasti Doupovských Hor. Ph. D. Thesis. Praha, 1975, pp. 130. 
KUTZER, E. - KNAUS, E.: Untersuchungen über die Endoparasitenfauna eines Rehbestandes in der freien Wildbahn. Z. Jagdwiss., 6, 1968: 62.

NEČAS, J. Srnči zvěř, 2. vyd. Praha, 1975, pp. 302.

NICKEL, S. - HIEPE, Th. - NESS, H. - PINGEL, H.: Beiträge zur Parasitofauna der DDR. 2. Mitteilung. Untersuchungen zum Helminthenvorkommen beim Reh (Capreolus capreolus). Angew. Parasitol., 19, 1978: 194-202.

PAPÁNEK, F.: Lesná zver a rekreácia. Les. práce, 53, 1974: 539-542.

PÁV, J. - MOTTL, S.: Vliv některých cizopasníkủ na tělesnou váhu srnčí zvěře. Věd. práce, VÚLHM, 11, 1958: 179-208.

PÁV, J. - ZAJÍCEK, D.: Helmintofauna jelení zvěře a dynamika jejího výskytu v oboře Janovice. Les. čas., 14, 1969: 517-522.

PELLÉRDY, L.: Coccidia and Coccidiosis. Budapest, 1965: 517-522.

PODKOWKA, T. - BOGATKO, W.: Choroby inwazyjne sarni, jeleni, w lowieskach lesnych. Las Polski, 21, 1970: 11.

SALLAC, A.: Referát o plicní červivosti. Spolk. čas. pro les., mysl., přírod., 40, 1911/12: 337-339.

SITOWSKI, S.: Müllerius capillaris (Strongylus) chez le chevreuil dans les Pieniny. Rozpraw. biol. med. wet., 16, 1939: 55-60.

SKRJABIN, K. I. - POPOVA, T. I.: Osnovy nematodologii. V. Strongyloidei životnych i čeloveka. Moskva, 1955: 93-223.

SKRJABIN, K. I. - ŠICHOBALOVA, N. P. - ŠULC, R. S. - POPOVA, T. I. - BOEV, S. N. - DELJAMURE, S. L.: Opredelitel parazitičeskich nematod. III. Strongyljaty. Moskva, 1952: 862 .

SKRJABIN, K. I. - SICHOBALOVA, N. P. - ŠULC, R. S.: Osnovy nematodologii. III. Trichostrongylidy životnych i čeloveka. Moskva, 1954, pp. 683.

SLAVÍK, F. a kol.: Československá vlastivěda, I. Pŕíroda. Praha, 1929, pp. 642.

STOICAN, E. - OLTEANU, G.: Beiträge zum Studium der Helminthofauna des Rehes (C. capreolus) in Rumänien. Probl. der Paraz., 7, 1959: 38-46.

SYROVÝ, S. a kol.: Atlas podnebí Ceskoslovenské republiky. Praha, 1958, pp. 105.

SULC, R. S. - KADENAZII, A. M.: Charakteristika trichostrongylidy Spiculopteragia alcis ot losja i kosuli. Tr. Grlan, 7, 1954: 151-160.

TOMÁNEK, J.: Příspěvek $\mathrm{k}$ poznání helmintofauny srnčí zvěře Severomoravského kraje. Vet. med. Praha, 12, 1967: 739-744.

VOSTÁL, Z.: Paraziti srnčí zvěře. Thesis, Praha, 1953.

VÝVLECKA, J.: Příčiny hynutí lovné zvěře. Sborník VŠZL, Brno, B, 8, 1960: 54-61.

WECKER, H.: Úber die populationsdynamische Bedeutung von Parasiten beim Rehwild. Waldhyg., 6, 1966: 205-214.

WETZEL, R.: Die Bekämpfung des Lungen- und Magenwurmbefalles beim Rehwild. Dtsch. Jaäger, 58, 1937: 641 .

ZÁHOR̂, Z.: Výskyt velké motolice (Fascioloides magna Basse, 1875) u srnčí zvěře. Veterinářstvi, 15, 1965: 322-324.

ZÁSMĚTA, V.: Ekonomika československé myslivosti. Praha, 1968, pp. 222.

ZÁSMĚTA, V. - ŚVARC, J. - HROMAS, J.: Myslivost. Praha, 1976, pp. 214.

Reprint requests should be addressed to MVDr. Vladimír Vetýška CSc., 38601 OVZ Strakonice, Písecká 128 